\title{
IAMJ
}

INTERNATIONAL

AYURVEDIC

MEDICAL JOURNAL

\section{A SINGLE ARM CLINICAL STUDY TO ASSESS UPASHAYATMAKA EFFECT OF TRITIYAKATPHALADI CHURNA IN TAMAKA SHWASA W.S.R TO BRONCHIAL ASTHMA}

\author{
$\underline{\text { Aditi D. Kulkarni }}{ }^{1}$, Raju Y. Timmapur ${ }^{2}$, Poornima ${ }^{3}$ \\ ${ }^{1}$ PG Scholar, ${ }^{2}$ Professor and Head ${ }^{3}$ Professor \\ Department of Roga Nidana Ayurveda Mahavidyalaya, Hubballi, Karnataka, India
}

Corresponding Author: aditikulkarni63@gmail.com

https://doi.org/10.46607/iamj1708102020

(Published online: October 2020)

Open Access

(C) International Ayurvedic Medical Journal, India 2020

Article Received: 25/09/2020 - Peer Reviewed: 02/10/2020 - Accepted for Publication: 04/10/2020

D) Check for updates

\section{ABSTRACT}

Shwasa is a Gambheera and Prana hara roga, which involves Pranavaha Srotas Avarodha, causing difficulty in Shwasa-Uchhshwasa. Shwasa roga is of 5 types. Tamaka shwasa is one of the gambheera vyadhis. It is a kapha pradhnya vyadhi, presenting with shwasa vega with tama pravesha. Bronchial Asthma is a disease characterized by airway obstruction that is reversible (not completely) either spontaneously or with treatment, airway inflammation, airway hyper responsiveness to a variety of stimuli. It interferes with daily activity, which may lead to life threatening attacks. Ayurveda gives a wide range of treatment modalities despite of the disease being a yapya vyadhi. Here 40 subjects diagnosed with tamaka shwasa, fulfilling the inclusion criteria were randomly selected. Tritiyakatphaladi churna with madhu as anupana was given orally. The objective of the study is to check whether the yoga gives an upashayatmaka effect.

Keywords: Tamaka shwasa, bronchial asthma, tritiyakatphaladi churna 


\section{INTRODUCTION}

Prana vayu is the most important amongst the Pancha vayu. Murdhini is its main sthana and its karmas are Shteevana, Kshavatu and Shwasa etc. ${ }^{1}$ Among the Abhyantara srotas, Pranavaha Srotas is the most important one, whose dushti causes Hikka, Shwasa, Kasa etc vyadhis. Acharya Charaka has explained five types of Shwasa roga, one among those is Tamaka Shwasa. He explains that it is a Kapha vatatmaka vyadhi and its udbhava sthana is Pitta sthana. ${ }^{2}$ Here vayu attains Pratilomagati and reaches Pranavaha srotas, takes Ashraya in Greeva and Shiras, causes dushti of Kapha leading to obstruction of Vayu and manifests Tamaka Shwasa. ${ }^{3}$ Acharya Sushruta explains that when Prana Vayu along with Kapha leaves the Prakruta karma and attains Urdhva gati, produces Shwasa-Udhvasa is called as Shwasa roga. Madhavakara explains that, Shwasa is Kapha vata anubandhi and Tamaka shwasa is Kapha Pradhanya. ${ }^{5}$ Ashtanga Hridaya Kara also opines that it is Kapha vata anubandhi. ${ }^{6}$ The laxanas are, Ateeva shwasa vega, Kasa vega, Kaphashteevana, Ghurghurakam, Shayana shwasa Peeditam etc. ${ }^{7} \mathrm{Ni}$ danas are excessive exposure to Vayu, Raja, Dhuma, Sheeta sthana, Sheetambu sevana, Aama dosha, Marmaghata, Ushna-sheeta padartha sevana. Nidanarthakari roga of Pandu, Atisara, Jwara and Chardi. ${ }^{8}$ Bronchial asthma- Asthma is a Greek word, which means Panting. It is difficult to define it as it is not one homogeneous condition and because there is no one objective measurement or series of measurements that can be used to make diagnosis of Asthma. The condition was previously considered as Bronco spastic disorder only. It is now recognized as Asthma and is primarily an inflammatory disease. Bronchial Asthma is a disease characterized by airway obstruction that is reversible (not completely) either spontaneously or with treatment, airway inflammation, airway hyper responsiveness to a variety of stimuli. Chronic inflammatory disorders of the airways in susceptible individuals, inflammatory symptoms are usually associated with widespread but variable airflow obstruction, and an increase in airway response. ${ }^{9}$ Epidemic proportions affecting 155 million individuals in the world. It is a condition which is most troublesome to all age groups with prevalence of 5-10\%. In youngsters' boys are more affected than girls and in adults' women are more affected than men. In India prevalence has been reported to $0.6 \%$ to $3.2 \%$ in rural and urban response is $4 \%$. A lot of factors are responsible for either causation or exacerbation of bronchial asthma. The causative factors may be allergies, infections, occupational environment, Rhinitis and sinusitis etc allergens include, pollen, house dust, food allergies. It has been recognized that viral respiratory infections provoke and alter asthmatic responses. Genetic factors also play a contributing role in pathogenesis of bronchial asthma. It is characterized by wide variation over short periods of time in resistance to flow in the airway. The hallmark of the disease is the airflow obstruction. Three factors narrow airway calibre to limit the flow. (1) Airway smooth muscle contraction. (2) Gland and epithelial secretion and exudation in the airway lumen. (3) Inflammatory oedema and vasodilatation. The epithelial shedding and influx of the Esinophills into the airway mucosa has been associated with Bronchial asthma. ${ }^{10}$ The symptoms include cough, wheezing, shortness of breath, chest tightness and modest degree of sputum production. There is no confirmatory diagnostic blood test, Lung function test; chest x-ray may help in the diagnosis. The line of treatment includes Pharmacological and nonpharmacological therapies. Nonpharmacological therapy includes patient and family education, environmental control, and immunotherapy. Pharmacological therapy includes, anti-inflammatory therapy, administration of Broncodilators etc. ${ }^{11}$ Upashaya is an Ahara or Vihara or Aushadi, which is Sukhanubandha (gives a soothing effect) to the patient and also pacifies the disease. When the laxanas are Goodha, Avyakta for diagnosis of the vyadhi, Upashaya and Anupashaya are helpful. If any Ahara, vihara or Aushadhi which is Hetu,vyadhi vipareeta that pacifies the symptoms it is the Upashaya of that particular disease. And if the condition worsens on administration it is the Anupashaya. ${ }^{12}$ Tritiyakatphaladi choorna ${ }^{13}$ is one such yoga explained in the Sharangadhara samhita, which has Katphala, Pushkaramoola, Pippali 
and Shringi with Madhu as Anupana. All these are Ushna and Teekshna guna yukta and have Kapha Vata hara action. Hence, they are Hetu vyadhi Vipareeta Aushadhi type of upashaya. According to the line of treatment of Tamaka Shwasa, the drugs having Vata Kaphagna and ushna properties are to be used in its treatment, keeping this principle; present study was carried out to assess the Upashayatmaka effect of Tritiyakatphaladi churna in Tamaka shwasa patients.

\section{Objectives of the Study}

- To study the Nidana Panchaka of Tamaka shwasa and aetiopathogenesis of bronchial asthma.

- To assess the upashayatmaka effect of Tritiyakatphaladichoorna on Tamaka shwasa.

\section{Inclusion Criteria}

- Subjects presenting with Pratyatma lakshana of Tamaka shwasa and cardinal symptoms of Bronchial asthma.

- Age group of 20-60 years irrespective of sex.

\section{Exclusion Criteria:}

- Pregnant women and lactating mother.

- Subjects presenting with Vega kaaleena Tamaka shwasa lakshana.

- Diabetes mellitus.
- Subjects suffering from HIV, HBsAg, Pulmonary Koch's.

- Breathlessness due to any other pathology other than Bronchial asthma.

Parameters of the study:

Subjective parameters ${ }^{14}$ :

Ateeva shwasa vega/Dyspnea; Kasa vega/cough; Kaphashteevana; Shayana shwasa peedita; Parshwa shola; Ghurghurakam/wheezing; Krichra bhaashitum; Aasino labhate sukham; Ushno sukham; Uchrito akshi; Lalaata sweda; mukha Shushukata; Megha ambu, sheeta vata, shleshma abhivardhate

\section{Objective Parameters:}

White blood cells; Absolute esinophil count; Erythrocyte sedimentation rate; Chest x-ray; Spirometry.

\section{Study Design:}

An observational clinical study, where a total of 40 subjects diagnosed with Tamaka shwasa were selected incidentally and randomly \& were studied under single group.

Grade of improvement:

Marked relief - Above 75\% improvement

Moderate relief - 50\%-75\% improvement

Mild relief - 25\%-50\% Improvement

No relief - Below 25\% improvement

\section{Observations and Results:}

Table 1: Nidana wise distribution of the patients

\section{Aharaja Hetu}

\begin{tabular}{|l|l|l|}
\hline Aharaja hetu & No. of Patients & Percentage \\
\hline Rukshanna & 14 & 35 \\
\hline Vishamashana & 23 & 57.5 \\
\hline Adhyashana & 33 & 82.5 \\
\hline Sheeta Ashana & 38 & 95 \\
\hline Sheeta pana & 35 & 87.5 \\
\hline Vidahi ahara & 11 & 27.5 \\
\hline Anoopa mamsa & 22 & 55 \\
\hline Pishtanna & 19 & 47.5 \\
\hline Guru ahara & 29 & 72.5 \\
\hline Shleshmala dravya & 29 & 72.5 \\
\hline Snigdha dravya & 32 & 80 \\
\hline
\end{tabular}


Table 2: Viharaja Hetu

\begin{tabular}{|l|l|l|}
\hline Viharaja Hetu & No. of Patients & Percentage \\
\hline Raja & 28 & 70 \\
\hline Dhuma & 12 & 30 \\
\hline Ati vyayama & 9 & 22.5 \\
\hline Sheeta sthana & 24 & 60 \\
\hline Sheeta ambu snana & 23 & 57.5 \\
\hline Vega dharana & 23 & 57.5 \\
\hline
\end{tabular}

Table 3: Purvarupa in 40 patients of Tamaka Shwasa

\begin{tabular}{|l|l|l|}
\hline Purvarupa & No. of Patients & Percentage \\
\hline Anaha & 11 & 27.5 \\
\hline Parshwashoola & 39 & 97.5 \\
\hline Hridaya peeda & 26 & 65 \\
\hline Bhakta dwesha & 30 & 75 \\
\hline Arti & 34 & 85 \\
\hline Adhmana & 15 & 37.5 \\
\hline Shankha nistoda & 14 & 35 \\
\hline
\end{tabular}

Table 4: Roopa in 40 patients of Tamaka Shwasa

\begin{tabular}{|l|l|l|}
\hline Laxanas & No. of Patients & Percentage \\
\hline Shwasa vega & 40 & 100 \\
\hline Kasa vega & 40 & 100 \\
\hline Kapha shteevana & 32 & 80 \\
\hline Shayana shwasa peeda & 39 & 97.5 \\
\hline Parshwashoola & 40 & 100 \\
\hline Ghurghurakam & 40 & 100 \\
\hline Krichra bhasha & 30 & 75 \\
\hline Ushna sukham & 39 & 97.5 \\
\hline Uchrito akshi & 33 & 82.5 \\
\hline Lalata sweda & 28 & 70 \\
\hline Mukha shushkata & 35 & 87.5 \\
\hline Sheeta Abhivardhanam & 40 & 100 \\
\hline Asino labhate sukham & 35 & 87.5 \\
\hline
\end{tabular}

Table 5: Effect of therapy on subjective parameters

\begin{tabular}{|c|c|c|c|c|c|c|c|c|}
\hline \multirow[t]{2}{*}{ Parameters } & \multicolumn{2}{|c|}{ MEAN } & \multirow{2}{*}{$\begin{array}{l}\text { Mean Differ- } \\
\text { ence }\end{array}$} & \multirow{2}{*}{$\begin{array}{l}\% \quad \text { OF } \\
\text { Relief }\end{array}$} & \multirow[t]{2}{*}{ S.D } & \multirow[t]{2}{*}{ S.E } & \multirow[t]{2}{*}{$Z^{\prime}$} & \multirow[t]{2}{*}{$\mathrm{P}$} \\
\hline & BT & AT & & & & & & \\
\hline Kasa vega & 2.33 & 0.35 & 1.98 & 79.58 & 0.62 & 0.098 & 20.18 & $<0.00001$ \\
\hline Shwasa vega & 2.13 & 0.18 & 1.95 & 89.17 & 0.5 & 0.079 & 24.64 & $<0.00001$ \\
\hline Kapha shteevana & 1.88 & 0.58 & 1.3 & 61.98 & 0.94 & 0.148 & 8.74 & $<0.00001$ \\
\hline Shayana shwasa peeda & 2.3 & 0.28 & 2.03 & 82.91 & 0.66 & 0.104 & 19.43 & $<0.00001$ \\
\hline Parshwashoola & 2.7 & 0.43 & 2.28 & 75 & 0.75 & 0.118 & 19.21 & $<0.00001$ \\
\hline Ghurghurakam & 2.55 & 0.28 & 2.28 & 83.33 & 0.68 & 0.107 & 21.19 & $<0.00001$ \\
\hline Krichra bhasha & 1.9 & 0.23 & 1.68 & 80.55 & 1.07 & 0.169 & 9.92 & $<0.00001$ \\
\hline Ushna sukham & 2 & 0.18 & 1.83 & 91.45 & 0.68 & 0.107 & 17 & $<0.00001$ \\
\hline
\end{tabular}




\begin{tabular}{|l|l|l|l|l|l|l|l|l|}
\hline Uchrita akshi & 2.05 & 0.1 & 1.95 & 92.42 & 1.04 & 0.164 & 11.85 & $<0.00001$ \\
\hline Lalata sweda & 1.68 & 0.15 & 1.55 & 90.23 & 1.13 & 0.178 & 8.66 & $<0.00001$ \\
\hline Mukha shushkata & 2.03 & 0.25 & 1.78 & 83.81 & 0.92 & 0.145 & 12.22 & $<0.00001$ \\
\hline Meghambu,sheetavata,abhivardhana & 2.48 & 0.85 & 1.63 & 52.08 & 0.67 & 0.106 & 15.37 & $<0.00001$ \\
\hline Asino labhate sukham & 2.2 & 0.25 & 1.98 & 82.86 & 0.95 & 0.15 & 13.17 & $<0.00001$ \\
\hline
\end{tabular}

Table 6: Effect of therapy on objective parameters

\begin{tabular}{|l|l|l|l|l|l|l|l|l|}
\hline \multirow{2}{*}{ Paramaters } & Mean & Mean Difference & \% Of Relief & S.D & S.E & $Z^{\prime}$ & P \\
\cline { 2 - 11 } & BT & AT & & & & & & \\
\hline TLC & 0.35 & 0 & 0.35 & 100 & 0.86 & 0.136 & 2.57 & 0.005085 \\
\hline ESR in males & 2.64 & 0.35 & 2.29 & 76.88 & 0.663 & 0.11 & 19.8 & $<0.00001$ \\
\hline ESR in females & 2.89 & 0.22 & 2.66 & 85.18 & 0.5 & 0.16 & 16.002 & $<0.00001$ \\
\hline Ratio of FVC/FEV1 & 1.78 & 0.75 & 1.05 & 68.8 & 0.51 & 0.08 & 13.01 & $<0.00001$ \\
\hline
\end{tabular}

Table 7: Overall Effect of Tritiyakatphaladi choorna on 40 Patients of Tamaka shwasa

\begin{tabular}{|l|l|l|l|}
\hline Relief & No. of Patients & Percentage & Remarks \\
\hline$>75 \%$ & 12 & 30 & MARKED RELIEF \\
\hline $50 \%-75 \%$ & 27 & 67.5 & MODERATE RELIEF \\
\hline $25 \%-50 \%$ & 1 & 2.5 & MILD RELIEF \\
\hline$<25 \%$ & 0 & 0 & NO RELIEF \\
\hline
\end{tabular}

\section{DISCUSSION}

Discussion helps in expansion of knowledge, by stimulation of thinking in a new way. The textual facts and the results obtained from the research have been discussed in this part. In general, "Shwasa" means respiration, it is a physiological phenomenon. When difficulty occurs in respiration it is called Shwasa roga.

In the shwasa roga the entire malfunction is done by Vata and kapha dosha. When we observe the nidanas mentioned in the classics they are divided into two categories, 1) which cause kapha dushti 2) which cause vata dushti.

The abnormality causing doshas mainly undergo two changes.

1. Kapha undergoes quantitative vridhi.

2. Vata takes pratiloma gati.

In the context of Tamaka shwasa, shamana chikitsa is given more importance than that of shodhana. Acharya Charaka states that any dravya having kapha-vata hara action, Ushna veerya, vata anulomana action should be taken for treatment.

Katphala has Kashayatikta and katu rasa pradhana, has ushna veerya and it has Kapha shamaka property. Pippali has Katu rasa, Snigdha, tikshna guna yukta, ushna veerya, has deepana and kasa hara action.
Karkataka shringi is Kashaya and tikta rasa pradhana, has laghu guna, ushna veerya. It has kapha vata hara action and it is mainly kasaghna._Pushkaramoola is tikta and katu rasa pradhanya. Tikshna, laghu guna yukta. Has ushna veerya. It has kapha vata hara action. It is hridya, shwasaghna and mainly acts on Parshwashoola

All the 40 patients showed complete reduction in the TLC after the therapy. 20 out of 31 male patients had shown marked reduction in the ESR, while 11 of them had a higher count even after the therapy. 7 out of 7 female patients showed marked reduction in the ESR, while 2 of them had maintained the counts. 39 patients had shown marked reduction in the AEC count after the therapy and 1 of them had slightly high count i.e. between 451-550. 12 patients had shown marked changes $(>80 \%)$ in the FVC: FEV1 ratio of spirometry readings. 28 of them had readings after therapy ranging between $79 \%-40 \%$. In the chest $\mathrm{x}$ - ray 8 patients had bronchial wall thickening before and after therapy, 7 of them showed reduction in bronchial wall thickening and 1 patient showed no changes even after the therapy. 39 patients had shown moderate to marked overall relief and 1 patient had not shown significant reduction in the symptoms. 


\section{CONCLUSION}

Tamaka shwasa is a condition which develops due to dushti of Avalambaka Kapha and Prana vayu. It is characterized by avarodha in Pranavaha srotas, agni vishamata and dushti of Pitta sthana.

The disease was commonly found in 41-60 age groups, who suffered from the disease for more than 10 years. Maximum of the subjects were male personnel's, belonged to middle class. Majority of them were govt employees, retired persons, lived in urban areas and mostly exposed to allergic factors, consumed mixed diet, had agnimandya, with disease running in the families. Maximum of them were of Kapha-vata prakruti, which is in accordance with the doshik predominance in the disease. Majority of them were smokers, tobacco chewers. The disease usually exacerbated in the winters and rainy seasons.

The majority of the nidanas observed were, exposure to Raja, dhuma, sheeta vata and other allergic factors, consumption of sheeta ahara, sheeta pana, shleshmala dravya, vataprakopaka dravyas and manasika factors, chinta, shoka.

Nidana parivarjana and ushnopachara was advised.

The drugs of the Tritiyakatphaladi choorna had following effects: Vata-Kapha hara, shwasa hara, antihistamine, anti-inflammatory effect and bronco spasm inhibition.

' $Z$ ' test was applied to the obtained data to analyse the results statistically. In 40 subjects, 12 (30\%) of them had marked relief, 27 (67.5\%) had moderate relief and $1(2.5 \%)$ had mild relief.

No adverse effects of the drugs were seen in any of the subjects.

\section{REFERENCES}

1. Vd. Harish Chandra Singh Kushavaha. The Charaka Samhita Ayurveda Dipika Ayushi Hindi commentary: 2012 edition, Chikitsa sthana $28^{\text {th }}$ chapter verse no.6, Choukamba Surbharati Prakashan Varanasi; volume 2: Pg.no: 730.

2. Vd. Harish Chandra Singh Kushavaha. The Charaka Samhita Ayurveda Dipika Ayushi Hindi commentary: 2012 edition, Chikitsa sthana $17^{\text {th }}$ chapter verse no.8,
Choukamba Surbharati Prakashan Varanasi; Pg.no: 445.

3. Vd. Harish Chandra Singh Kushavaha. The Charaka Samhita Ayurveda Dipika Ayushi Hindi commentary: 2012 edition, Chikitsa sthana $17^{\text {th }}$ chapter verse no. 55, Choukamba Surbharati Prakashan Varanasi; volume 2: Pg.no: 454-455.

4. Dr. Keval Krishna Thakral. Maharshi sushrutena vicharita Sushruta samhita shree Dalhanacharya evum Gayadasa Virachita hindi commentary: 2017 edition, Uttara tantra $51^{\text {st }}$ chapter verse no. 4, Choukambha Orientalia publication Varanasi; volume 3: Pg no: 484.

5. Ayurvedacharya Yadunandan upadhyaya. Mahamati shree Madhavakara virachitam Madhava nidanam Madhukosha commentary: 2018 edition, Choukambha Prakashan Varanasi; chapter no. 12, Pg no 332.

6. Kaviraj Atridev Gupta. Shreemad Vagbhata virachitam Ashtanga hridayam vidyatini hindi commentary: 2017 edition, Nidana sthana, Chapter no.4: choukambha prakashan Varanasi. Pg no. 314.

7. Vd. Harish Chandra Singh Kushavaha. The Charaka Samhita Ayurveda Dipika Ayushi Hindi commentary: 2012 edition, Chikitsa sthana $17^{\text {th }}$ chapter verse no. 56, Choukamba Surbharati Prakashan Varanasi; volume 2: Pg.no: 454.

8. Vd. Harish Chandra Singh Kushavaha. The Charaka Samhita Ayurveda Dipika Ayushi Hindi commentary: 2012 edition, Chikitsa sthana $17^{\text {th }}$ chapter verse no. 1116, Choukamba Surbharati Prakashan Varanasi; volume 2: Pg no: 446.

9. D.Behera. Textbook of pulmonary medicine, $2^{\text {nd }}$ edition, published in 2010, Jaypee brother's medical publishers, Chapter 15; Volume 1: Pg.no: 865.

10. D.Behera. Textbook of pulmonary medicine, $2^{\text {nd }}$ edition, published in 2010, Jaypee brother's medical publishers, Chapter 15; Volume 1: Pg.no: 882.

11. D.Behera. Textbook of pulmonary medicine, $2^{\text {nd }}$ edition, published in 2010, Jaypee brother's medical publishers, Chapter 15; Volume 1: Pg.no: 906.

12. Madhavakara, Sri Vijayarakshita, Shrikanthadatta.Madhava Nidana, Madhukosha Sanskrit commentary (edited by Prof. Yadunandanopadhyaya), edition 2018, Choukamba Surbharati Prakashan; Volume 1: Pg.no:13.

13. Dr. Bramhanand Tripathi. Sharangadhara samhita of Sharangadhara acharya, Anjana nidana of maharshi Agnivesha, Dipika hindi commentary, Chaukamba Surbharati publication, Madhyama khanda, Chapter $6^{\text {th }}$, verse 43: Pg.no:179. 
14. Vd. Harish Chandra Singh Kushavaha. The Charaka Samhita Ayurveda Dipika Ayushi Hindi commentary: 2012 edition, Chikitsa sthana $17^{\text {th }}$ chapter, shloka no 56-62, Choukamba Surbharati Prakashan Varanasi; volume 2: Pg.no: 454

\section{Source of Support: Nil}

\section{Conflict of Interest: None Declared}

How to cite this URL: Aditi D. Kulkarni et al: A Single Arm Clinical Study To Assess Upashayatmaka Effect Of Tritiyakatphaladi Churna In Tamaka Shwasa W.S.R To Bronchial Asthma. International Ayurvedic Medical Journal \{online\} 2020 \{cited October, 2020\} Available from: http://www.iamj.in/posts/images/upload/4677_4683.pdf 